\title{
A systematic review and meta-analysis on the use of prophylactic topical antibiotics for the prevention of uncomplicated wound infections
}

This article was published in the following Dove Press journal: Infection and Drug Resistance

Qiao-Jing Tong,' Kimberly DP Hammer, ${ }^{2,3}$ Erika M Johnson, ${ }^{4}$ Milagros Zegarra, ${ }^{2,3}$ Michihiko Goto, ${ }^{5,6}$ Tze Shien Lo ${ }^{3,7}$

'Department of Infection Control, Sir Run Run Shaw Hospital, School of Medicine, Zhejiang University, Hangzhou, Zhejiang, China; ${ }^{2}$ Research Service, Fargo VA Health Care System; ${ }^{3}$ Department of Internal Medicine, University of North Dakota, School of Medicine and Health Sciences, Fargo, ND, USA; ${ }^{4}$ Library Resources, University of North Dakota, School of Medicine and Health Sciences, Fargo, ND, USA; ${ }^{5}$ Center for Comprehensive Access \& Delivery Research \& Evaluation (CADRE), lowa City VA Health Care System, West lowa City, IA, USA; ${ }^{6}$ Department of Internal Medicine, University of lowa, Carver College of Medicine, lowa City, IA, USA ${ }^{7}$ Infectious Disease Service, Fargo VA Health Care System, Fargo, ND, USA

\section{Video abstract}

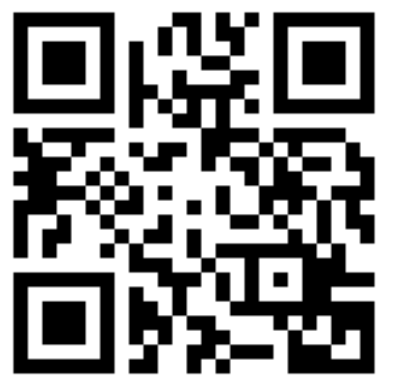

Point your SmartPhone at the code above. If you have a QR code reader the video abstract will appear. Or use: http://youtu.be/ $10 y \mathrm{~N}-0 \mathrm{AB} 66 \mathrm{~g}$

Correspondence: Tze Shien Lo Fargo VA Health Care System, Infectious Diseases Service, 2101 Elm St N, Fargo, ND 58102 , USA

Tel + I 7012323241 ext 3509

$\mathrm{Fax}+\mathrm{I} 7012934145$

Email Tze.Lo@va.gov
Background: The prescription of topical antibiotics for the prevention of infections in uncomplicated wounds is common. However, the efficacy is not well reported. Therefore, the objective of the study was to conduct a systematic review and meta-analysis of the available evidence on prevention of uncomplicated wound infections by prophylactic topical antibiotics.

Materials and methods: The search included Pubmed, Google Scholar, SCOPUS, Embase, Cochrane, ClinicalTrials.gov, International Clinical Trials Registry Platform, National Technical Information Service, and the National Guidelines Clearinghouse.

Results: We identified eight randomized controlled trials and four quasi-randomized trials that met the criteria for the systematic review. Of these trials, 11 studies were pooled for metaanalysis to compare the effects of topical antibiotics versus placebo and 4 studies were pooled for comparison of effects of topical antibiotics versus topical antiseptics on uncomplicated wounds. Fewer wound infections occurred in the topical antibiotic arms compared to placebo (pooled risk ratio: 0.57 [95\% CI: 0.37 to 0.86$] ; p=0.01$ and pooled risk difference: $-3.1 \%$ [95\% CI: $-5.8 \%$ to $-0.34 \%] ; p=0.03$ ). Compared to antiseptics, topical antibiotics demonstrated statistically significant relative risk reduction (pooled risk ratio: 0.56 [95\% CI: 0.23 to 0.91 ]; $p=0.02$ ), while there was no significant absolute risk reduction (pooled risk difference: $-3.7 \%$ [95\% CI: $-7.9 \%$ to $+0.6 \%$ ]; $p=0.09$ ).

Conclusion: Topical antibiotics are effective in reducing wound infections after surgical procedures, but the absolute benefit is small. Given the global emergence of antimicrobial resistance, judicious use of antibiotics is encouraged and use of antiseptics should be considered as a reasonable alternative to topical antibiotics.

Keywords: topical antibiotics, prevention, wound infections

\section{Introduction}

Uncomplicated wound infections account for almost 200 million physician visits in the USA annually, with treatment costs estimated to be $>\$ 350$ million each year. ${ }^{1}$ Patients with uncomplicated wound infections are commonly treated with topical antimicrobial therapy for several reasons, including the high local drug concentration at the site of the infection, ${ }^{2}$ the low incidence of systemic side effects, ${ }^{3}$ and good patient compliance.

Although there is little debate about the need to keep these wounds clean and provide a moist environment for wound healing, ${ }^{4}$ there is still controversy over the use of topical antibiotics, including the possibility of local allergic reactions to topically applied antimicrobials or their vehicles, poor penetration into the skin, and emergence of resistant organisms with antibiotics exposure. ${ }^{5}$ 
Saco et al concluded from their systematic review and meta-analysis that petroleum should be used instead of topical antibiotics for prevention of postsurgical wound infections. ${ }^{6}$ The Centers for Disease Control and Prevention 2017 guideline for the prevention of surgical site infections (SSIs) compiled by the Healthcare Infection Control Practices Advisory Committee also recommended against the use of topical antimicrobial agents for prevention of SSIs. However, these recommendations were based on low-quality evidence. ${ }^{7}$ On the other hand, through their systematic review and metaanalysis, Heal et al concluded topical antibiotics probably prevent SSIs compared to no antibiotic or with antiseptic. ${ }^{8}$

Because of the controversy in the use of topical antibiotics for prevention of SSIs, we conducted a systematic review and a meta-analysis to examine the available evidence of the clinical effectiveness of topical antibiotic use for prevention of uncomplicated wound infections.

\section{Materials and methods Literature search}

The authors conducted this systematic review and metaanalysis in accordance with the Preferred Reporting Items for Systematic Reviews and Meta-Analyses recommendations. ${ }^{9}$

One of the authors (EMJ) searched Pubmed, Google Scholar, and SCOPUS (which includes content from the Embase database). Additionally, Cochrane, ClinicalTrials.gov, International Clinical Trials Registry Platform, National Technical Information Service, and the National Guidelines Clearinghouse were searched. The search was limited to human subjects and English language literature published in and after 1980. The last search was performed in July 2017.

The following search strategy comprising the Medical Subject Headings (MeSH) and keywords was used: ("skin/ injuries" [Majr] OR "wound healing” [Majr] OR "wound infection/prevention and control" [Majr] OR "infection control/methods" [Majr] OR "bacterial infections/prevention and control" [Majr]) OR ("uncomplicated" AND ["wound" OR "laceration"] OR "infection prophylaxis" OR "infection prevention") AND ("anti-infective agents, local” [MeSH] OR "anti-bacterial agents" [MeSH] OR "triple antibiotic" OR “neosporin” OR "polysporin”) AND ("administration, topical” [MeSH] OR "administration, cutaneous" [MeSH] OR "topical” OR "cutaneous"). References of all included articles were scanned for additional studies. Articles focusing on dermatologic surgeries were included. Articles focusing on treatment rather than prevention and those not focusing on uncomplicated skin infection were excluded.

\section{Selection}

We included randomized controlled trials and quasirandomized trials (QRTs) with no limitation for age, sex, or country of origin. We defined uncomplicated wounds as wounds that were acute and uninfected. We defined prophylaxis or prevention as administration of topical antibiotics to the wounds before development of infection. We included studies that examined uncomplicated wounds and had topical antibiotics in the form of ointment, cream, paste, or gel in at least one of the study arms. Studies that used lotion, solution, tincture, foam, paste, powder, tulle, aerosols, or antibiotic-impregnated dressing were included if one of the study arms used ointment, cream, paste, or gel as one of the topical antibiotics. We also included studies that had an antiseptic (e.g., silver sulfadiazine cream, povidone-iodine) or a placebo or no treatment as a comparison arm. Wounds that were already infected at the time of enrollment and burn wounds were excluded. Studies on artificially created wounds and those that involved catheters were also excluded.

\section{Outcomes}

The primary outcome was the development of postsurgical or post-procedural wound infections.

\section{Trial selection and data extraction}

Three reviewers (TSL, KDPH, and MZ) independently reviewed the 4314 articles found during the initial database searching. The data were then extracted based on eligibility criteria, data sources, study methods, sample sizes, types of intervention, post-procedural wound infection rates, and authors' conclusions.

\section{Assessment of risk of bias}

The three reviewers who performed the trial selection and data extraction also evaluated the included studies for the risk of bias (selection bias, performance bias, detection bias, attrition bias, and reporting bias) based on Cochrane Collaboration's tool for assessing risk of bias. ${ }^{10}$

\section{Statistical analysis}

Mantel-Haenszel random-effects models were used to pool dichotomous count data across studies and estimate the risk ratios (RRs), risk differences (RDs), and their corresponding 95\% CIs to assess relative and absolute effect sizes of efficacy. Our primary exposure was the use of any topical antibiotics, and primary outcome was development of wound infection following surgical procedure. $I^{2}$ and $\tau^{2}$ were calculated to assess heterogeneity among the included studies. We stratified 
analysis by the type of comparison (placebo and antiseptics) and also summarized results by tested antimicrobial agents. We performed meta-analysis if more than or equal to three studies were available for the same analysis group. Numbers needed to treat (NNTs) were also calculated based on RDs for primary analysis. Statistical analyses were conducted using SAS version 9.4 (SAS Institute, Cary, NC, USA), and forest plot was created using Review Manager (RevMan) version 5.3 (Cochrane Collaboration, Copenhagen, Denmark).

\section{Results}

The results of the literature search are shown in the flowchart in Figure 1. Initially, 4314 potentially relevant articles were identified through our initial database searching. After reviewing the titles and abstracts, 4274 articles were excluded and 40 full-text articles were eligible for detailed examination. Out of the 40 full-text articles, 28 articles were excluded based on the reasons cited in Figure 1. Eight randomized controlled trials and four QRTs met the criteria for inclusion in the systematic review. The characteristics of the 12 studies included in the systematic review are summarized in Table 1. Among them, eight studies reported comparison between topical antimicrobials and placebo, one reported comparison between topical antimicrobials and topical antiseptics, and three studies included both placebo and topical antiseptics as comparison arms.

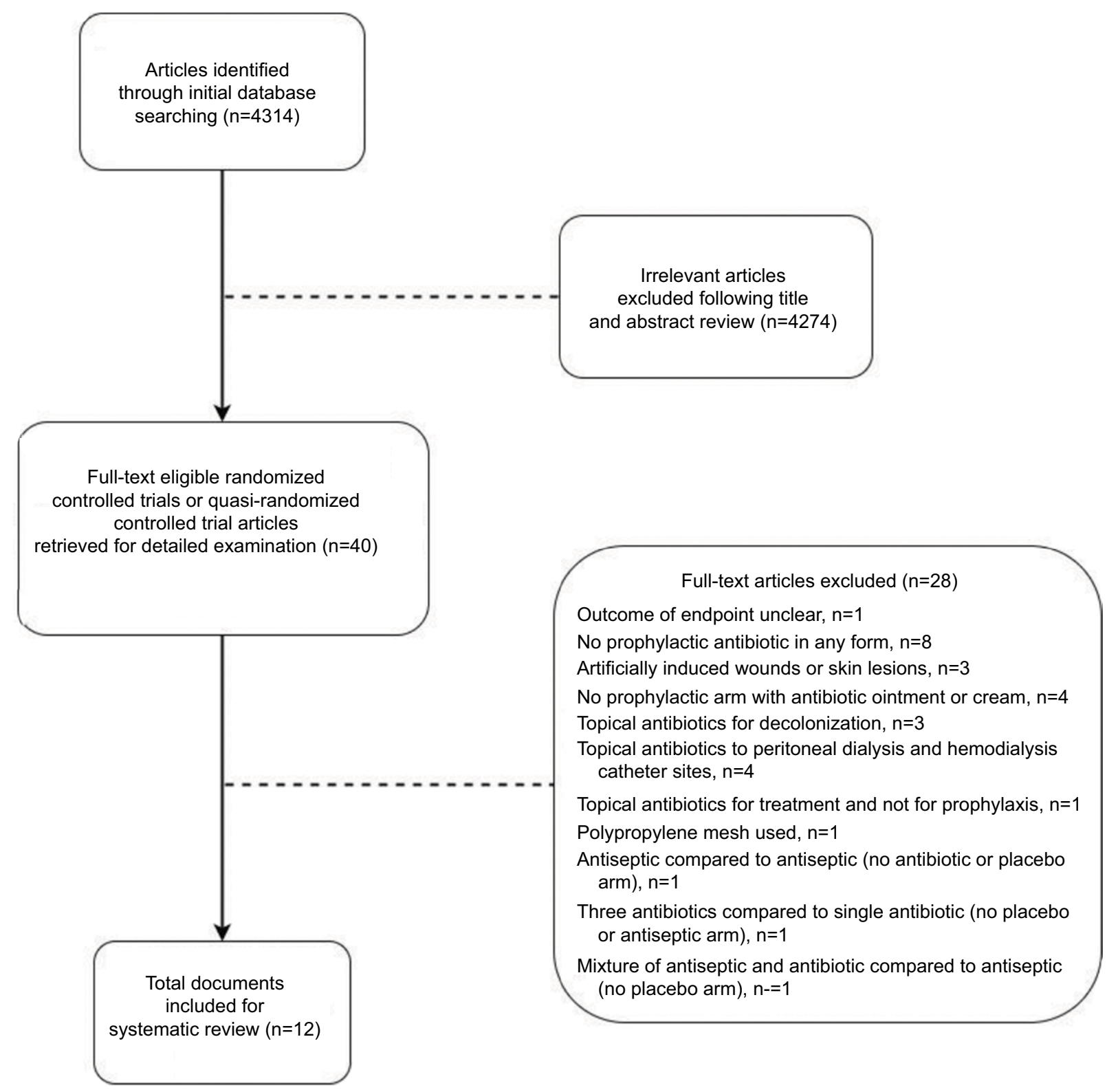

Figure I Literature search flow chart. 
Table I Characteristics of the 12 studies included in the systematic review

\begin{tabular}{|c|c|c|c|c|c|}
\hline $\begin{array}{l}\text { Data source/ } \\
\text { study location }\end{array}$ & $\begin{array}{l}\text { Type of trial - } \\
\text { QRT or RCT }\end{array}$ & $\begin{array}{l}\text { Study methodology } \\
\text { and sample size }\end{array}$ & Interventions & $\begin{array}{l}\text { Wound infection } \\
\text { rates }\end{array}$ & Authors' conclusion \\
\hline $\begin{array}{l}\text { Campbell et al"1/ } \\
\text { USA }\end{array}$ & QRT & $\begin{array}{l}\text { Prospective, non- } \\
\text { blinded, randomized trial } \\
\text { I } 40 \text { patients } \\
\text { I } 47 \text { wounds }\end{array}$ & $\begin{array}{l}\text { Self-application by } \\
\text { subjects: } \\
\text { I. Gentamicin } \\
\text { ointment } \\
\text { 2. Petrolatum }\end{array}$ & $\begin{array}{l}\text { Postop suppurative } \\
\text { chondritis } \\
\text { I. } 4 / 84=4.76 \% \\
\text { 2. } 4 / 60=6.67 \%\end{array}$ & $\begin{array}{l}\text { No difference between the } \\
\text { use of gentamicin ointment } \\
\text { and petrolatum in preventing } \\
\text { postoperative auricular } \\
\text { suppurative chondritis }\end{array}$ \\
\hline Dire et al ${ }^{12} /$ USA & $\mathrm{RCT}$ & $\begin{array}{l}\text { Prospective, } \\
\text { randomized, double- } \\
\text { blinded, placebo- } \\
\text { controlled trial } \\
465 \text { patients } \\
465 \text { wounds }\end{array}$ & $\begin{array}{l}\text { I. Bacitracin } \\
\text { 2. BPN } \\
\text { 3. Silver sulfadiazine } \\
\text { 4. Petrolatum }\end{array}$ & $\begin{array}{l}\text { I. } 6 / 109=5.5 \% \\
\text { 2. } 5 / 1110=4.5 \% \\
\text { 3. } 12 / 99=12.1 \% \\
\text { 4. } 19 / 108=17.6 \%\end{array}$ & $\begin{array}{l}\text { Use of topical antibiotics } \\
\text { resulted in significantly lower } \\
\text { infection rates }\end{array}$ \\
\hline $\begin{array}{l}\text { Dixon et al }{ }^{13 /} \\
\text { Australia }\end{array}$ & $\mathrm{RCT}$ & $\begin{array}{l}\text { Prospective, blinded, } \\
\text { RCT } \\
778 \text { patients } \\
\text { I80I wounds }\end{array}$ & $\begin{array}{l}\text { I. Mupirocin } \\
\text { 2. Paraffin } \\
\text { 3. No ointment prior } \\
\text { to placement of } \\
\text { moist occlusive } \\
\text { dressings }\end{array}$ & $\begin{array}{l}\text { I. } 13 / 562=2.3 \% \\
\text { 2. } 12 / 729=1.6 \% \\
\text { 3. } 7 / 510=1.4 \%\end{array}$ & $\begin{array}{l}\text { Applying ointment on a surgical } \\
\text { wound before occlusive dressing } \\
\text { does not benefit the patients }\end{array}$ \\
\hline $\begin{array}{l}\text { Draelos et } \mathrm{al}^{14} / \\
\text { USA }\end{array}$ & $\mathrm{RCT}$ & $\begin{array}{l}\text { Double-blinded, } \\
\text { multicenter trial } \\
30 \text { patients } \\
60 \text { wounds }\end{array}$ & $\begin{array}{l}\text { I. Non-antibiotic } \\
\text { aquaphor healing } \\
\text { ointment } \\
\text { 2. Polymyxin/ } \\
\text { bacitracin ointment }\end{array}$ & $\begin{array}{l}\text { No wound infection } \\
\text { noticed for both } \\
\text { groups }\end{array}$ & $\begin{array}{l}\text { No differences were seen } \\
\text { between the two groups in } \\
\text { stinging, itching, tightness, } \\
\text { tingling, or pain. One case of } \\
\text { contact dermatitis was noticed } \\
\text { in the polymixin/bacitracin } \\
\text { group }\end{array}$ \\
\hline $\begin{array}{l}\text { Heal et al }{ }^{15 /} \\
\text { Australia }\end{array}$ & $\mathrm{RCT}$ & $\begin{array}{l}\text { Prospective, } \\
\text { randomized, placebo- } \\
\text { controlled, double- } \\
\text { blinded, multicenter trial } \\
972 \text { patients } \\
972 \text { wounds }\end{array}$ & $\begin{array}{l}\text { I. Chloramphenicol } \\
\text { ointment } \\
\text { 2. Paraffin ointment }\end{array}$ & $\begin{array}{l}\text { I. } 32 / 488=6.6 \% \\
\text { 2. } 53 / 484=11 \%\end{array}$ & $\begin{array}{l}\text { The incidence of infection in } \\
\text { the chloramphenicol group } \\
\text { was significantly lower than the } \\
\text { control group }\end{array}$ \\
\hline Kamath et $\mathrm{al}^{16 / \mathrm{UK}}$ & $\mathrm{RCT}$ & $\begin{array}{l}\text { Randomized controlled, } \\
\text { blinded trial } \\
92 \text { patients }\end{array}$ & $\begin{array}{l}\text { I. Topical I\% } \\
\text { chloramphenicol } \\
\text { ointment } \\
\text { 2. No } \\
\text { chloramphenicol } \\
\text { ointment }\end{array}$ & $\begin{array}{l}\text { I. } 4 / 47=8.5 \% \\
\text { 2. } 8 / 45=17.8 \%\end{array}$ & $\begin{array}{l}\text { The risk of developing wound } \\
\text { infection was not significant } \\
\text { with and without the use of } \\
\text { chloramphenicol ointment }\end{array}$ \\
\hline $\begin{array}{l}\text { Khalighi et al }{ }^{17 /} \\
\text { USA }\end{array}$ & QRT & $\begin{array}{l}\text { Randomized, placebo- } \\
\text { controlled trial } \\
\text { I008 patients }\end{array}$ & $\begin{array}{l}\text { I. Providone iodine } \\
\text { ointment } \\
\text { 2. Neomycin ointment } \\
\text { 3. Sterile non- } \\
\text { adherent pads } \\
\text { 4. Non-antibiotic, non- } \\
\text { antiseptic "placebo" } \\
\text { (standard dressing) }\end{array}$ & $\begin{array}{l}\text { 1. } 4 / 257=1.5 \% \\
\text { 2. } 2 / 263=0.7 \% \\
\text { 3. } 4 / 240=1.6 \% \\
\text { 4. } 4 / 248=1.6 \%\end{array}$ & $\begin{array}{l}\text { The use of topical antibiotics } \\
\text { after closure has not shown } \\
\text { significant benefit }\end{array}$ \\
\hline $\begin{array}{l}\text { Langford et al }{ }^{18 /} \\
\text { Australia }\end{array}$ & QRT & $\begin{array}{l}\text { Randomized, double- } \\
\text { blinded, prospective trial } \\
107 \text { patients } \\
177 \text { wounds }\end{array}$ & $\begin{array}{l}\text { I. } \mathrm{CBP} \\
\text { 2. PIC } \\
\text { 3. Placebo gel }\end{array}$ & $\begin{array}{l}\text { Clinical infection } \\
\text { I. } 1 / 62=1.6 \% \\
\text { 2. } 2 / 67=3 \% \\
\text { 3. } 6 / 48=12.5 \% \\
\text { Micrologic infection } \\
\text { I. } 4 / 48=1.6 \% \\
\text { 2. } 2 / 67=3 \% \\
\text { 4. } 4 / 48=8.5 \%\end{array}$ & $\begin{array}{l}\text { CBP reduced the incidence of } \\
\text { clinical infections }\end{array}$ \\
\hline
\end{tabular}


Table I (Continued)

\begin{tabular}{|c|c|c|c|c|c|}
\hline $\begin{array}{l}\text { Data source/ } \\
\text { study location }\end{array}$ & $\begin{array}{l}\text { Type of trial - } \\
\text { QRT or RCT }\end{array}$ & $\begin{array}{l}\text { Study methodology } \\
\text { and sample size }\end{array}$ & Interventions & $\begin{array}{l}\text { Wound infection } \\
\text { rates }\end{array}$ & Authors' conclusion \\
\hline $\begin{array}{l}\text { Maddox et al } 19 / \\
\text { USA }\end{array}$ & RCT & $\begin{array}{l}\text { Prospective, double- } \\
\text { blinded trial } \\
59 \text { patients } \\
\text { Number of wounds not } \\
\text { mentioned }\end{array}$ & $\begin{array}{l}\text { I. BPN } \\
\text { 2. Placebo }\end{array}$ & $\begin{array}{l}\text { I. } 4 / 27=15 \% \\
\text { 2. } 15 / 32=47 \%\end{array}$ & $\begin{array}{l}\text { Topical antibiotics may be usefu } \\
\text { in preventing streptococcal } \\
\text { pyoderma }\end{array}$ \\
\hline $\begin{array}{l}\text { Pradhan and } \\
\text { Agrawal }{ }^{20} / \mathrm{Nepal}\end{array}$ & QRT & $\begin{array}{l}\text { Open-label randomized } \\
\text { trial } \\
70 \text { female patients } \\
\text { Number of wounds not } \\
\text { mentioned }\end{array}$ & $\begin{array}{l}\text { I. Topical fusidic acid } \\
\text { after absorbable } \\
\text { subcuticular stitches } \\
\text { 2. Povidone-iodine } \\
\text { dressing }\end{array}$ & $\begin{array}{l}\text { I. } 1 / 35=2.8 \% \\
\text { 2. } 6 / 35=17.1 \%\end{array}$ & $\begin{array}{l}\text { The use of fusidic acid reduced } \\
\text { the infection rate by six times }\end{array}$ \\
\hline Smack et $\mathrm{a}^{21} / \mathrm{USA}$ & RCT & $\begin{array}{l}\text { Prospective, } \\
\text { randomized, double- } \\
\text { blinded trial } \\
884 \text { patients } \\
\text { I } 207 \text { wounds }\end{array}$ & $\begin{array}{l}\text { I. Bacitracin ointment } \\
\text { 2. WP prior to } \\
\text { occlusive wound } \\
\text { dressings }\end{array}$ & $\begin{array}{l}\text { I. } 4 / 444=0.9 \% \\
\text { 2. } 9 / 440=2.0 \%\end{array}$ & $\begin{array}{l}\text { WP is a safe and equally } \\
\text { effective wound care ointment } \\
\text { for surgical wound prophylaxis } \\
\text { compared to bacitracin }\end{array}$ \\
\hline Taylor et $\mathrm{a}^{122} / \mathrm{USA}$ & $\mathrm{RCT}$ & $\begin{array}{l}\text { Double-blinded, split- } \\
\text { face study } \\
20 \text { patients } \\
40 \text { wounds }\end{array}$ & $\begin{array}{l}\text { I. Aquaphor healing } \\
\text { ointment } \\
\text { 2. Polymyxin B } \\
\text { +bacitracin }\end{array}$ & $\begin{array}{l}\text { No infection } \\
\text { occurred during the } \\
\text { study }\end{array}$ & $\begin{array}{l}\text { Antibiotics are not necessary } \\
\text { for effective healing of facial } \\
\text { wounds }\end{array}$ \\
\hline
\end{tabular}

Abbreviations: BPN, bacitracin +polymyxin +neomycin; CBP, cetrimide +bacitracin +polymyxin; PIC, povidone-iodine cream; QRT, quasi-randomized trial; RCT, randomized controlled trial; WP, white petrolatum.

\section{Risk of bias}

Out of the 12 included studies, we concluded 2 were at high risk of bias, ${ }^{11,20} 4$ were at unclear risk, ${ }^{13,14,17,22}$ and 6 were at low risk..$^{12,15,16,18,19,21}$ We found detailed descriptions were lacking for random sequence generation and/or allocation concealment in four studies that were considered at unclear risk. There were two studies that were considered at high risk because of their open-label design and both studies were in the category of QRTs. None of the high-risk or unclear risk studies committed attrition bias or reporting bias.

\section{Efficacy of topical antibiotics compared to placebo}

In total, 11 studies (5240 wounds) were pooled to compare the effects of topical antibiotics versus placebo on uncomplicated wounds (Figures 2 and 3). Meta-analysis for RRs showed statistically significant relative risk reduction (pooled RR: 0.57 [95\% CI: 0.37 to 0.86 ]; $p=0.01$ ), while meta-analysis for $\mathrm{RD}$ demonstrated statistically significant but small absolute risk reduction (pooled RD: $-3.1 \%$ [95\% CI: $-5.8 \%$ to $-0.34 \%$; $p=0.03$ ). Estimated NNT based on absolute risk reduction was 32.4 (95\% CI: 17.2 to 294.4). Two studies could not be included in the meta-analysis for RRs because of zero count of event. Of the 11 studies, 1 was at high risk, 4 were at unclear risk, and 6 were at low risk of bias.

\section{Efficacy of topical antibiotics compared to topical antiseptics}

Four studies (total of 1037 wounds) reported comparison between topical antibiotics and topical antiseptics (Figures 4 and 5). Meta-analysis for RRs showed statistically significant relative risk reduction (pooled RR: 0.56 [95\% CI: 0.34 to 0.91]; $p=0.02$ ), while meta-analysis for RD did not show significant absolute risk reduction (pooled RD: $-3.7 \%[95 \%$ CI: $-7.9 \%$ to $+0.6 \%] ; p=0.09$ ). Of the four studies, one was at high risk, one was at unclear risk, and two were at low risk of bias.

\section{Summary of included studies by antimicrobial agents}

Figure 6 summarizes the results of included studies by the type of antimicrobial agents used, compared to placebo or antiseptics. Since no specific antimicrobial agent had adequate number of studies, we could not perform metaanalysis of individual agents.

\section{Discussion}

Our systematic review and meta-analysis found that topical antibiotics in comparison to placebo or antiseptics reduced postsurgical procedure infection risk, albeit a small absolute risk reduction. Because the NNT to prevent one additional 


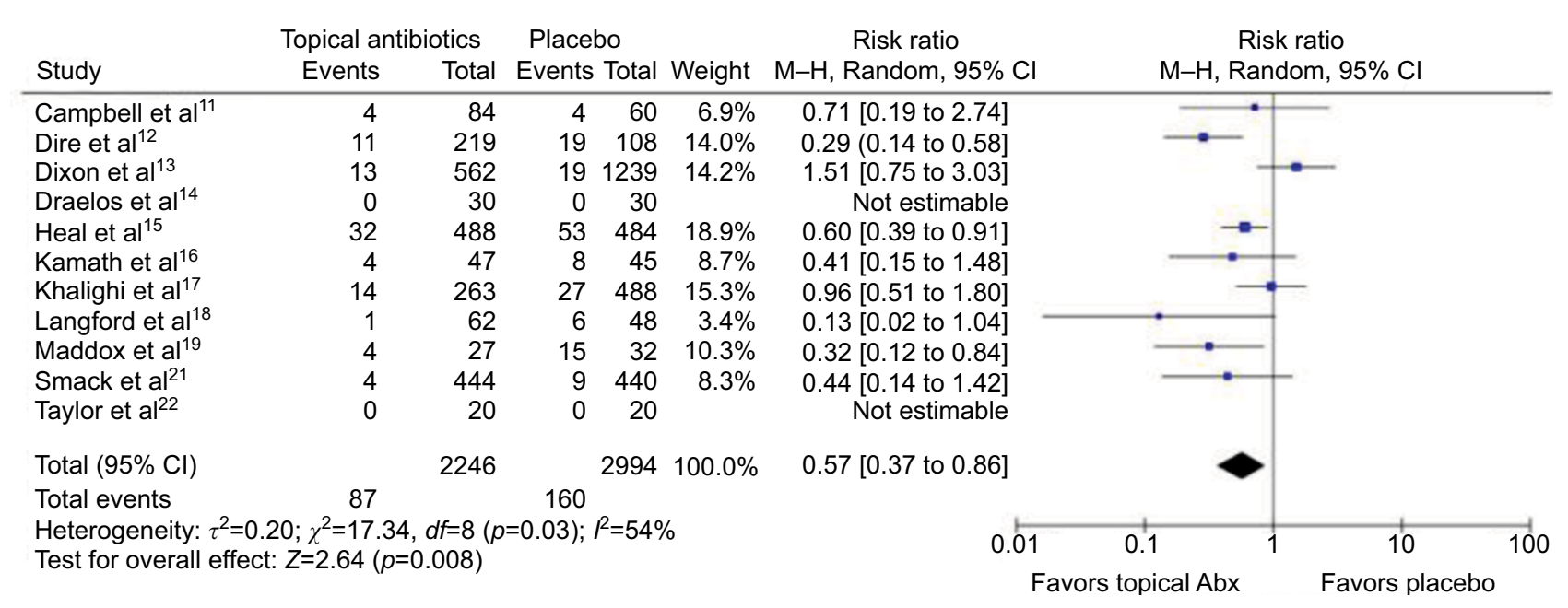

Figure 2 Forest plot showing the risk ratio of topical antibiotics versus placebo on uncomplicated wounds. Abbreviations: Abx, antibiotics; df, degrees of freedom; M-H, Mantel-Haenszel.

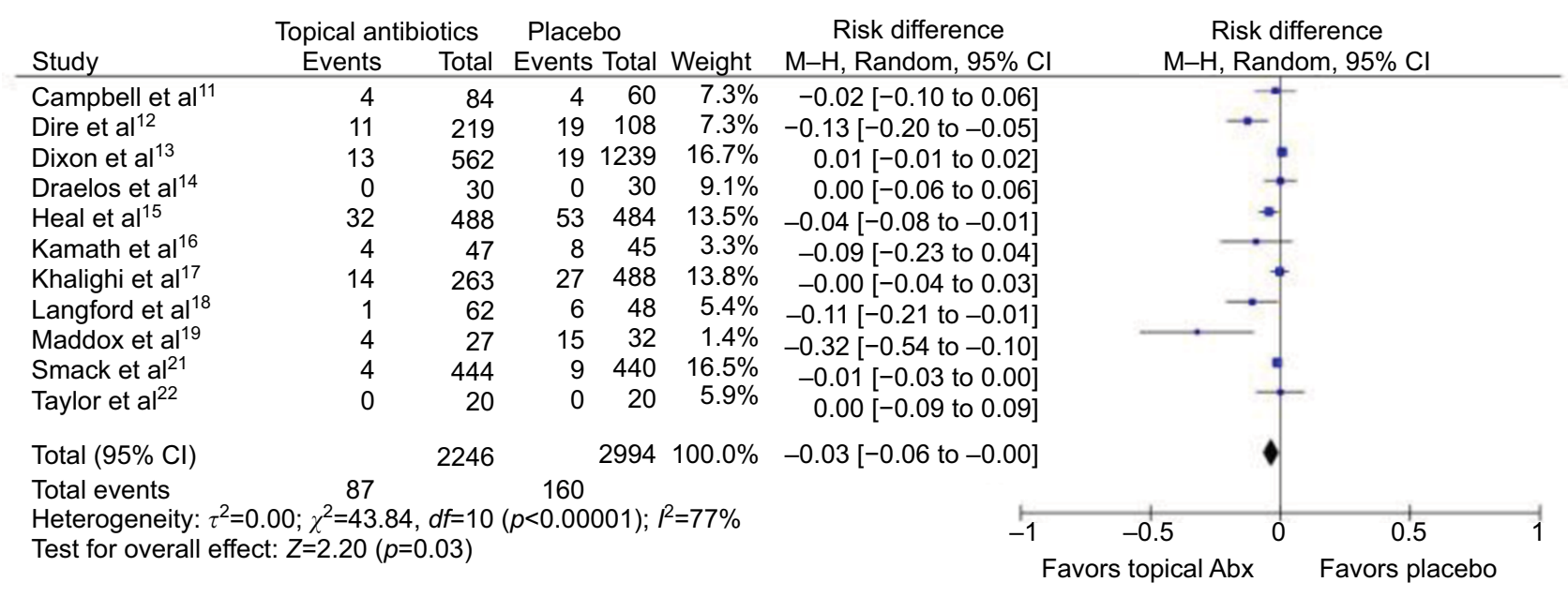

Figure 3 Forest plot showing the risk difference of topical antibiotics versus placebo on uncomplicated wounds. Abbreviations: Abx, antibiotics; df, degrees of freedom; M-H, Mantel-Haenszel.

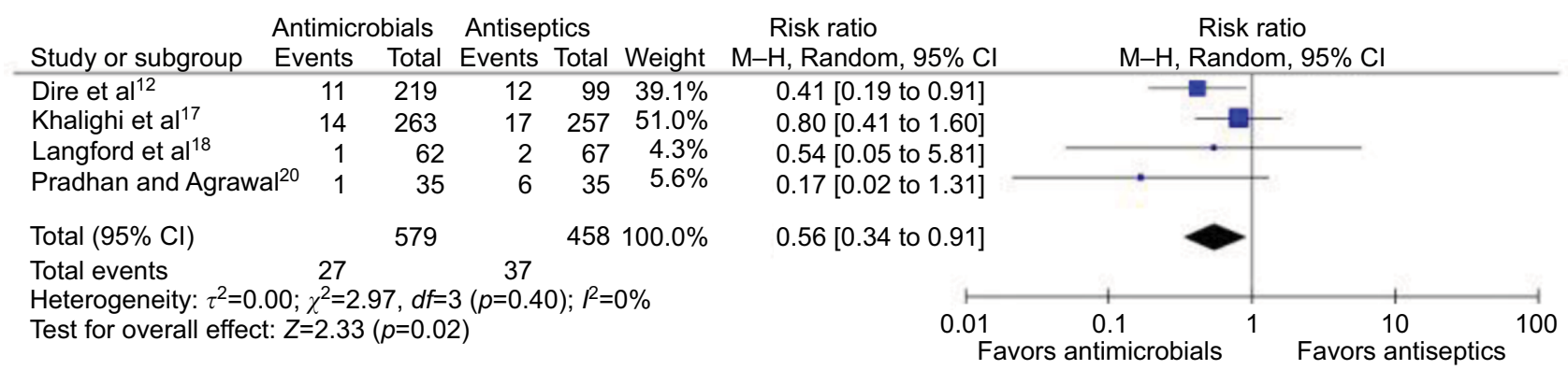

Figure 4 Forest plot showing the risk ratio of topical antibiotics versus antiseptic on uncomplicated wounds.

Abbreviations: $d f$, degrees of freedom; $M-H$, Mantel-Haenszel.

case of wound infections was 32.4 and the risk reduction of topical antibiotics versus placebo and topical antibiotics versus antiseptics was only $-3.1 \%$ and $-3.7 \%$, respectively, we concluded that the absolute benefit of topical antibiotic is small.
It was not possible to draw conclusions regarding the effect of topical antibiotics on complicated wound infections or uncomplicated wounds that had been infected prior to application of topical antibiotics, since this was outside the scope of this systematic review and meta-analysis. 


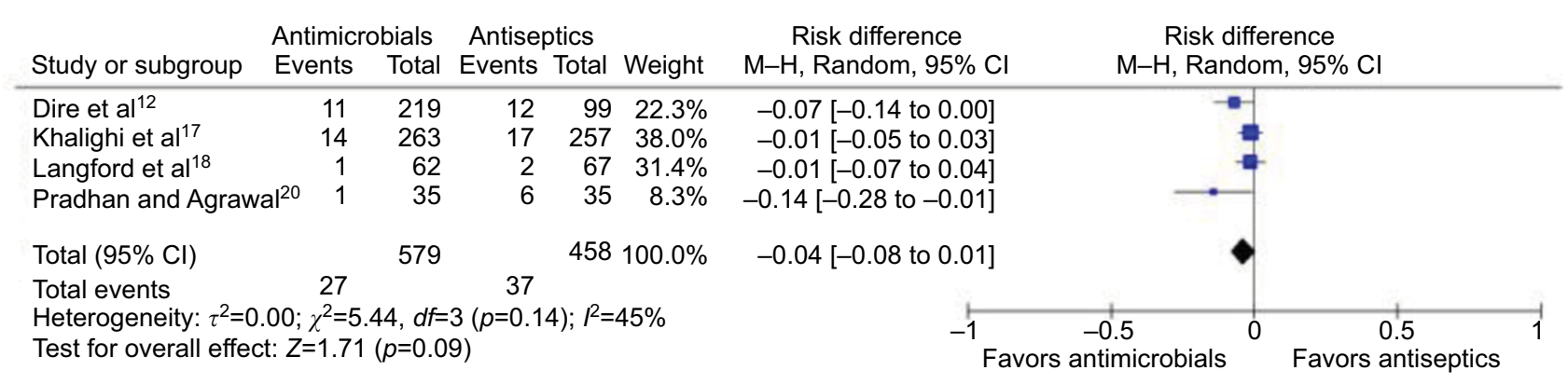

Figure 5 Forest plot showing the risk difference of topical antibiotics versus antiseptic on uncomplicated wounds.

Abbreviations: $\mathrm{df}$, degrees of freedom; $\mathrm{M}-\mathrm{H}$, Mantel-Haenszel.

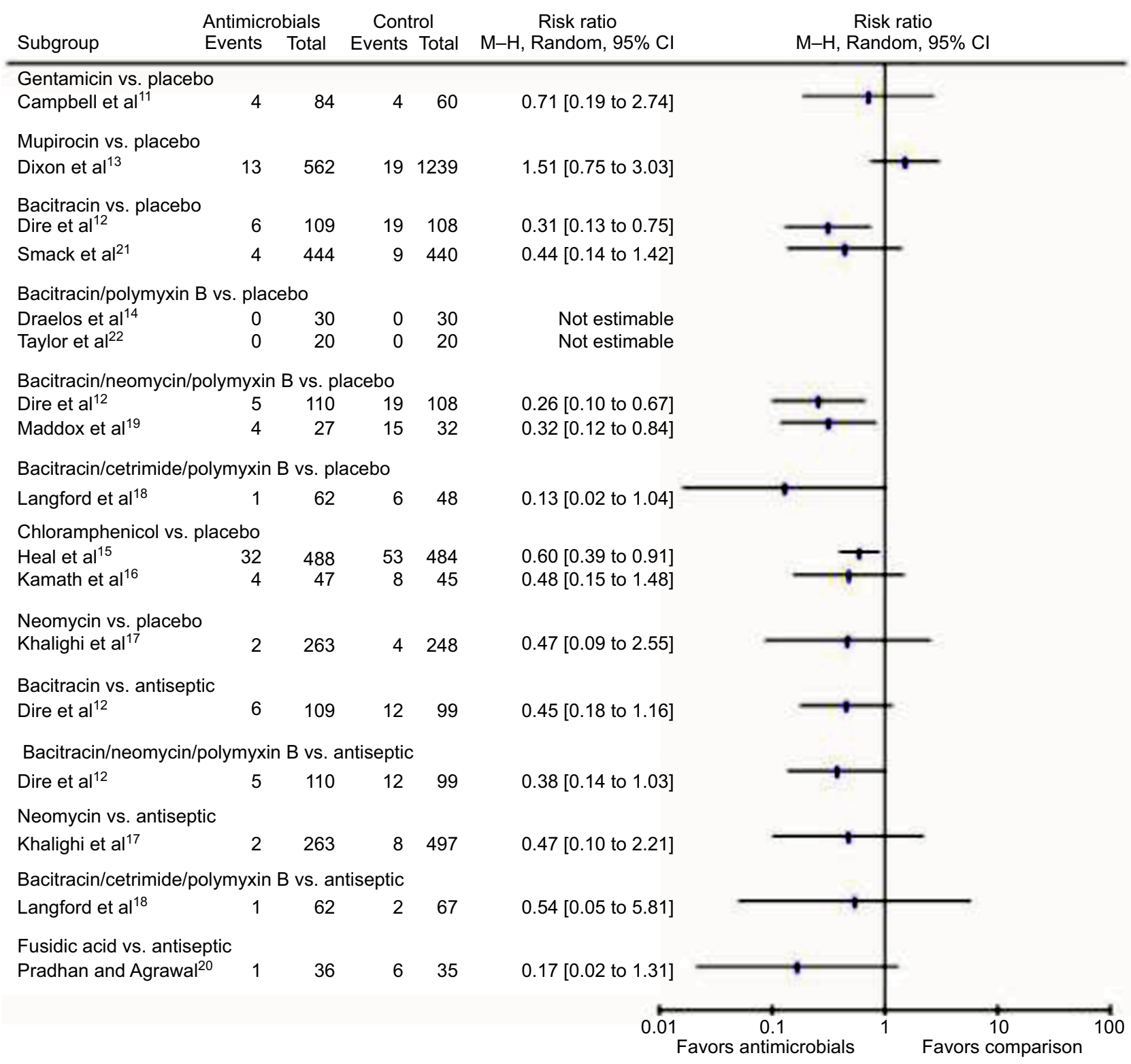

Figure 6 Summarized results by the type of antimicrobial agents used. Abbreviation: $\mathrm{M}-\mathrm{H}$, Mantel-Haenszel. 
Our study has a few limitations. First, only studies that were published in the English language since 1980 were included, therefore we could have excluded articles that were pertinent to our review. Second, many studies assessing the efficacy of topical antibiotics for wounds have varying study designs, which does not allow for direct comparisons. In addition, definitions of wound or description of wounds included were not always clearly defined within the publications. Another limitation of our study was we did not investigate the adverse reactions to topical antibiotics in comparison to placebo, such as allergic contact dermatitis. However, the incidence of adverse reactions related to topical antibiotics is known to be low ${ }^{23,24}$ and there were very few studies that addressed this topic.

One of the strengths of our review was the inclusion of studies that used antibiotic cream, ointment paste, or gel as they are the most commonly used vehicles for topical antibiotics that allow for a high concentration at the site of infection. Another strength was comparison of individual topical antibiotics to placebo or antiseptic, which was not done in similar studies. ${ }^{6,8}$

While the evidence presented demonstrates that topical antibiotics are effective for prevention of wound infections after surgical procedures, clinicians must take into consideration the toxicity risk of the compound, efficacy, and that there is little information on systemic absorption of the antibiotics. Furthermore, route of administration of antibiotics should be carefully considered. As discussed above, this systematic review focused on topical application of antibiotics because this route of administration is the most commonly used for uncomplicated skin infections.

\section{Conclusion}

Topical antibiotics were effective in reducing the risk of infections in uncomplicated wounds compared to placebo or antiseptics, but the absolute risk reduction was minimal compared to placebo. In addition, there was no statistically significant absolute reduction when compared to antiseptics. Considering the global emergence of antimicrobial resistance, judicious use of topical antibiotics is encouraged, and antiseptics should be considered as a reasonable alternative to topical antibiotics.

\section{Acknowledgments}

This study was supported by grants from the Health and Family Planning Commission of Zhejiang Province (grant number 2014KYA113). This material is the result of work supported with resources and use of facilities at the Fargo Veterans Affairs Health Care System. All data included in this systematic review and meta-analysis were aggregated from previously published sources and have been collected from anonymous subjects.

\section{Disclosure}

The authors report no conflicts of interest in this work.

\section{References}

1. Pangilinan R, Tice A, Tillotson G. Topical antibiotic treatment for uncomplicated skin and skin structure infections: review of the literature. Expert Rev Anti Infect Ther. 2009;7(8):957-965.

2. Alsterhold M, Karami N, Faergemann J. Antimicrobial activity of topical skin pharmaceuticals - an in vitro study. Acta Derm Venereol. 2010;90(3):239-245.

3. O'Meara S, Al-Kurdi D, Ologun Y, Ovington LG, Martyn-St. James M, Richardson R. Antibiotics and antiseptics for venous leg ulcers. Cochrane Database Syst Rev. 2014;10(1):CD003557.

4. Korting HC, Schollmann C, White RJ. Management of minor acute cutaneous wounds: importance of wound healing in a moist environment. J Eur Acad Dermatol Venereol. 2011;25(2):130-137.

5. Waterbrook AL, Hiller K, Hays DP, Berkman M. Do topical antibiotics help prevent infection in minor traumatic uncomplicated soft tissue wounds? Ann Emerg Med. 2013;61(1):8688.

6. Saco M, Howe N, Nathoo R, Cherpalis B. Topical antibiotic prophylaxis for prevention of surgical wound infections from dermatologic procedures: a systemic review and meta-analysis. $J$ Dermatolog Treat. 2015;26(2):151-158.

7. Berrios-Torres SI, Umscheid CA, Bratzler DW, et al; Healthcare Infection Control Practices Advisory Committee. Centers for disease control and prevention guideline for the prevention of surgical site infection, 2017. JAMA Surg. 2017;152(8):784-791.

8. Heal CF, Banks JL, Lepper P, Kontopantelis E, Van Driel ML. Metaanalysis of randomized and quasi-randomized clinical trials of topical antibiotics after primary closure for the prevention of surgical-site infection. Br J Surg. 2017;104(9):1123-1130.

9. Moher D, Shamseer L, Clarke M, et al; PRISMA-P Group. Preferred reporting items for systematic review and meta-analysis protocols (PRISMA-P) 2015 statement. Syst Rev. 2015;4(1):1-9.

10. Higgins JP, Altman DG, Gøtzsche PC, et al; Cochrane Bias Methods Group; Cochrane Statistical Methods Group. The cochrane collaboration's tool for assessing risk of bias in randomised trials. $B M J$. 2011;343:d5928.

11. Campbell RM, Perils CS, Fisher E, Gloster HM Jr. Gentamicin ointment versus petrolatum for management of auricular wounds. Dermatol Surg. 2005;31(6):664-669.

12. Dire DJ, Coppola M, Dwyer DA, Lorette JJ, Karr JL. Prospective evaluation of topical antibiotics for preventing infections in uncomplicated soft-tissue wounds repaired in the ED. Acad Emerg Med. 1995;2(1):4-10.

13. Dixon AJ, Dixon, MP, Dixon JB. Randomized clinical trial of the effect of applying ointment to surgical wounds before occlusive dressing. $\mathrm{Br}$ J Surg. 2006;93(8):937-943.

14. Draelos ZD, Rizer RL, Trookan NS. A comparison of postprocedural wound care treatments: do antibiotic-based ointments improve outcomes? J Am Acad Dermatol. 2011;64(3 Suppl):S23-S29.

15. Heal CF, Buettner PG, Cruickshank R, et al. Does single application of topical chloramphenicol to high risk sutured wounds reduce incidence of wound infection after minor surgery? Prospective randomized placebo controlled double blind trial. BMJ. 2009;338:a2812. 
16. Kamath S, Sinha S, Shaari E, Young D, Campbell AC. Role of topical antibiotics in hip surgery: a prospective randomized study. Injury. 2005;36(6):783-787.

17. Khalighi K, Aung TT, Elmi F. The role of prophylaxis topical antibiotics in cardiac device implantation. Pacing Clin Electrophysiol. 2014;37(3):304-311.

18. Langford JH, Artemi P, Benrimoj SI. Topical antimicrobial prophylaxis in minor wounds. Ann Pharmacother. 1997;31(5):559-563.

19. Maddox JS, Ware JC, Dillon HC Jr. The natural history of streptococcal skin infection: prevention with topical antibiotics. JAm Acad Dermatol. 1985;13(2 Pt 1):207-212.

20. Pradhan GBN, Agrawal J. Comparative study of post-operative wound infection following emergency lower segment caesarean section with and without the topical use of fusidic acid. Nepal Med Coll J. 2009;11(3):189-191.
21. Smack DP, Harrington AC, Dunn C, et al. Infection and allergy incidence in ambulatory surgery patients using white petrolatum vs bacitracin ointment. A randomized controlled trial. JAMA. 1996;276(12): 972-977.

22. Taylor SC, Averyhart AN, Heath CR. Postprocedural wound-healing efficacy following removal of dermatosis papulose nigra lesions in an African American population: a comparison of a skin protectant ointment and a topical antibiotic. J Am Acad Dermatol. 2011;64(3 Suppl): S30-S35.

23. Gehrig KA, Warshaw EM. Allergic contact dermatitis to topical antibiotics: epidemiology, responsible allergens, and management. Cont Med Educ. 2008;58(1):1-20.

24. Gette MT, Marks JG Jr, Maloney ME. Frequency of postoperative allergic contact dermatitis to topical antibiotics. Arch Dermatol. 1992;128(3):365-367.
Infection and Drug Resistance

\section{Publish your work in this journal}

Infection and Drug Resistance is an international, peer-reviewed openaccess journal that focuses on the optimal treatment of infection (bacterial, fungal and viral) and the development and institution of preventive strategies to minimize the development and spread of resistance. The journal is specifically concerned with the epidemiology of antibiotic

\section{Dovepress}

resistance and the mechanisms of resistance development and diffusion in both hospitals and the community. The manuscript management system is completely online and includes a very quick and fair peerreview system, which is all easy to use. Visit http://www.dovepress.com testimonials.php to read real quotes from published authors. 